\title{
DNA damage to nervous tissue due to lead intoxication combined with glucose loading
}

\author{
N.L. Yakimova \\ Estern-Siberian Institute of Medical \\ and Ecological Research, \\ Angarsk, Russia \\ ynl-77@1ist.ru
}

\author{
E.S. Andreeva \\ Estern-Siberian Institute of Medical \\ and Ecological Research, \\ Angarsk, Russia
}

\author{
E.V. Buinova \\ Estern-Siberian Institute of Medical \\ and Ecological Research, \\ Angarsk, Russia
}

\begin{abstract}
The effects of heavy metals on different organs and systems are known. Disorders in diabetes are also well understood. The compounding contribution of glucose loading was manifested in the increase of genotoxic lesions of nerve cells caused by lead intoxication. The DNA damage in the tail of nerve cell comets after exposure to lead and glucose loading increased to $52.86(13.16$ 73.34) percent compared to $25.28(12.24-54.79)$ percent of leadintoxicated individuals. In lead-exposed and glucose-affected animals, cells with high DNA damage in the tail of comets dominated the brain, $62.77(54.68-70.87)$ percent of cells were apoptosis positive compared to $48.42(38.37-58.47)$ percent of rats receiving lead acetate without glucose loading.
\end{abstract}

Keywords - lead; glucose loading; nervous system; DNA damage

\section{Motivation and aim}

According to observations from 2008 to 2017, many localities in the Russian Federation are included in the list with moderately dangerous and dangerous categories of lead contamination of soil, air and water bodies. The effects of heavy metals on various organs and systems, including DNA damage and apoptotic processes, have been studied [1,2]. Studies of diabetes mellitus on experimental models are relevant [3], but its genotoxic effects on the nervous system are not well understood. There is also a lack of genotoxicity data for lead intoxication combined with metabolic disorders. Research on these aspects is important for improving preventive measures and early diagnosis of health problems caused by aggravating factors in the workers and the population.

The aim was to study genotoxic changes in nerve cells in lead intoxication, which was aggravated by glucose loading in rats.

\section{Methods}

The experiment was performed on adult male rats. The animals were divided into three groups of 12 . The control individuals were in group 1 . Rats in group 2 received lead acetate daily at a dose of $50 \mathrm{mg} / \mathrm{kg}$ bw (calculated as metal) with drinking water for 30 days. In animals group 3 simulated lead acetate intoxication under similar conditions and simultaneously injected glucose at a dose of $6000 \mathrm{mg} / \mathrm{kg}$ bw twice a day at an interval of 6 hours for 30 days. Behavioral reactions were studied by means of the test «open field». The DNA damage in the brain tissue was evaluated using the «DNA comet» method.

\section{Results}

Under conditions of heavy metal exposure and glucose injection, there has been a reduction in locomotor and research activity in rats. The DNA content of the comet's tail reflects the extent of DNA damage. In lead exposure and glucose loading in rats of group 3, DNA damage in nerve cells increased compared to animals after lead poisoning "Table 1".

TABLE 1

\begin{tabular}{|c|c|c|c|}
\hline The level of & \multicolumn{3}{|c|}{ DNA content in the tail of a comet $(\%)$} \\
\hline $\begin{array}{l}\text { in the brain } \\
\text { cells of } \\
\text { experimental } \\
\text { animals, } \\
\mathrm{Me}(\mathrm{Q} 25-\mathrm{Q} 75)\end{array}$ & $\begin{array}{l}1 \text { group } \\
\text { Control }\end{array}$ & $\begin{array}{c}2 \text { group } \\
\text { Lead acetate }\end{array}$ & $\begin{array}{l}3 \text { group } \\
\text { Lead } \\
\text { acetate+ } \\
\text { glucose }\end{array}$ \\
\hline brain & $\begin{array}{l}8.72(0- \\
25.69)\end{array}$ & $\begin{array}{c}25.28(12.24- \\
54.79)^{* 1}\end{array}$ & $\begin{array}{c}52.86(13.16- \\
73.34)^{* 2,{ }^{*} 1}\end{array}$ \\
\hline
\end{tabular}

In rats, simulated intoxication combined with glucose loading, the amount of DNA in the comet's tail in the brain was significantly higher than in individuals after exposure to lead acetate $(p=0.0019)$ and compared to the control group $\left(p=3.808^{*} E^{-15}\right)$. The largest amount of intact DNA was observed in the brain of the comet in control group cells, and the smallest - in group 3 rats.

Apoptosis is considered to be those cells in which the tail of comets contains more than $30 \%$ of the damaged DNA. Overall, in rats of group 3, there was an increase in the number of apoptosis-positive cells to $62.77(54.68-70.87) \%$, compared to $48.42(38.37-58.47) \%$, in individuals of group $2(\mathrm{p}=0.035)$, and compared to $18.71(12.22-25.19) \%$, in the control group $(\mathrm{p}=0.0001)$. So, in animals with lead intoxication, combined with glucose loading, cells with high DNA damage in the tail of comets dominated.

\section{ACKNOWLEDGMENT}

Supported by the state task on the program of search scientific researches.

\section{REFERENCES}

[1] Y. Ahmed, H. Eldebaky, K.Gh.M. Mahmoud, M. Nawito "Effects of lead exposure on DNA damage and apoptosis in reproductive and vital organs in female rabbits," Global Veterinaria, 9, pp. 401-408, 2012.

[2] S. Jadoon, A. Malik, "DNA damage by heavy metals in animals and human beings: an overview," Biochem. Pharmacol., 6, pp. 1000235 , 2017.

[3] M. Küçük, R.B. Kalayci, A. Çevik, I. Elmas, M. Kaya, "Effect of aluminum on the blood - brain barrier permeability in acute and chronically hyperglycemic rats," Biol. Trace Elem. Res., 80, pp. 181-189, 2001. 